\title{
Prevalence Survey of Selected Bovine Pathogens in Water Buffaloes in the North Region of Brazil
}

\author{
Jenevaldo Barbosa da Silva, ${ }^{1}$ Priscilla Nunes dos Santos, ${ }^{2}$ \\ Gustavo Nunes de Santana Castro, ${ }^{2}$ Adivaldo Henrique da Fonseca, ${ }^{2}$ \\ and José Diomedes Barbosa ${ }^{3}$ \\ ${ }^{1}$ Laboratório de Imunoparasitologia, Departamento de Patologia Veterinária, Faculdade de Ciências Agrárias e \\ Veterinárias FCAV-UNESP, Via de Acesso Professor Paulo Donato Castellane s/n, 14884-900 Jaboticabal, SP, Brazil \\ ${ }^{2}$ Laboratório de Doenças Parasitárias, Departamento de Epidemiologia e Saúde Pública, Universidade Federal Rural de \\ Rio de Janeiro (UFRRJ), BR $465 \mathrm{Km}$ 7, 23890-000 Seropédica, RJ, Brazil \\ ${ }^{3}$ Instituto de Medicina Veterinária, Universidade Federal do Pará (UFPA), Rodovia BR 316 Km 61, \\ Bairro Saudade, 68740-970 Castanhal, PA, Brazil \\ Correspondence should be addressed to Jenevaldo Barbosa da Silva; jenevaldo@hotmail.com
}

Received 30 August 2013; Accepted 4 November 2013; Published 19 January 2014

Academic Editor: Fabio Ribeiro Braga

Copyright (C) 2014 Jenevaldo Barbosa da Silva et al. This is an open access article distributed under the Creative Commons Attribution License, which permits unrestricted use, distribution, and reproduction in any medium, provided the original work is properly cited.

\begin{abstract}
Although the largest buffalo herd in the occident is in the north region of Brazil, few studies have been conducted to assess the prevalence of selected parasitic diseases in buffalo herd. The present study was therefore conducted to investigate the epidemiological of Toxoplasma gondii, Neospora caninum, Anaplasma marginale, Babesia bigemina, and Babesia bovis in water buffaloes in the north region of Brazil. A total of 4796 buffalo blood samples were randomly collected from five provinces and simultaneously analyzed by the IFAT and ELISA. The serological prevalence of T. gondii and N. caninum was $41.3 \%$ and $55.5 \%$ in ELISA and $35.7 \%$ and $48.8 \%$ in IFAT, respectively. The overall prevalence of A. marginale, B. bovis, and B. bigemina was $63 \%$, $25 \%$, and $21 \%$ by ELISA and $50.0 \%, 22.5 \%$, and $18.8 \%$ by IFAT, respectively. This study shows valuable information regarding the serological survey of selected bovine pathogens in water buffaloes in the north region of Brazil which will likely be very beneficial for the management and control programs of this disease.
\end{abstract}

\section{Introduction}

Brazil has the biggest western buffalo herd, where approximately $65 \%$ of which is located in the north region of this country [1]. Nowadays, the buffalo has been highlighted in the national scenery, showing more than just an alternative to the occupation of lands unsuitable for cattle but becoming an economically important option. As consequence, concern about sanitary management has increased considerably, because the clinical, pathological, and epidemiological studies are still poorly studied in Latin America.

Buffaloes, when compared to other domestic livestock, are generally a resistance animal [2]. This is particularly impressive because most of them, especially the water buffaloes, live in hot and humid regions that are willing to have several infectious agents [2]. Although the reason is not clear, the effect on buffaloes is often less deleterious than that on cattle.

Toxoplasmosis is a widespread zoonosis caused by the coccidian protozoan Toxoplasma gondii which can parasitize human beings and many warm-blooded animals, inducing abortions and neonatal mortality in small ruminants [3]. Neospora caninum is structurally and biologically similar to Toxoplasma gondii [4], causing abortion and neonatal mortality in cattle, sheep, goats, and horses in many countries [5]. Anaplasma marginale, Babesia bovis, and Babesia bigemina are important tick-borne agents of cattle worldwide [6]. Although many studies have been conducted worldwide on the prevalence of these important pathogens in animals, few studies have been conducted on water buffaloes in 
Latin America [7-9]. The present work aimed to assess the prevalence of $N$. caninum, T. gondii, A. marginale, B. bovis, and $B$. bigemina among water buffaloes in the north region of Brazil.

\section{Materials and Methods}

2.1. Serum Samples. Field samples of blood from water buffalo $(n=4796)$ were collected from different farms in eight provinces in Marajó island (Soure, Salvaterra, Muaná, Chaves, Ponta de Pedras, Cachoeira do Arari, and Santa Cruz do Arari) and five provinces in Continent (Belém, Castanhal, Paragominas, Abaetetuba, and Mojú) in the north region of Brazil in 2011. The minimum sample size was calculated by the following formula of the Pan American Zoonoses Center [10]:

$$
N=\frac{p *(100-p) Z^{2}}{(d * p / 100)^{2}},
$$

where $N$ is the number of samples; $p$ is the expected prevalence; $Z$ is the degree of confidence; $d$ is the margin of error

The expected prevalence for selected bovine pathogens of buffaloes was estimated to be $7 \%$. The confidence interval was $95 \%$, and the margin of error was $5 \%$. Thus, the minimum sample size was 3,650 animals, and a total of 4,796 animals were used in this study. Whole blood samples were collected from caudal or jugular vein of individual water buffaloes. For serum samples, blood samples without EDTA were incubated at room temperature and then centrifuged at $3000 \mathrm{rpm}$ for $15 \mathrm{~min}$; the sera were collected and then stored at $-20^{\circ} \mathrm{C}$ until use.

2.2. ELISA for B. bovis, B. bigemina, T. gondii, N. caninum, and A. marginale. Briefly, $100 \mu \mathrm{L}$ of each antigen diluted in $0.05 \mathrm{M}$ carbonate/bicarbonate buffer, $\mathrm{pH}$ 9.6, was added to each well of a micro-ELISA plate (Immulon; Dynatech Laboratories Inc.) and protein concentration was adjusted to $5 \mu \mathrm{g} / \mathrm{mL}$ (B. bovis, B. bigemina and T. gondii) or $10 \mu \mathrm{g} / \mathrm{mL}(N$. caninum, and $A$. marginale). The plates were sealed and incubated overnight at $4^{\circ} \mathrm{C}$. Plates were blocked for $1 \mathrm{~h}$ at $37^{\circ} \mathrm{C}$ in a humid chamber with 3\% skim milk in carbonate/bicarbonate buffer. After five washes with buffer (phosphate buffered saline, $\mathrm{pH} 7.2$, and $0.05 \%$ Tween 20 , PBS-Tween), $100 \mu \mathrm{L}$ of diluted bovine sera $(1: 400)$ in PBS-Tween plus 5\% normal rabbit serum was added in duplicate to the ELISA plate. Plates were incubated at $37^{\circ} \mathrm{C}$ in a humid chamber for $90 \mathrm{~min}$ and then washed five times with PBS-Tween. A $100 \mu \mathrm{L}$ aliquot of a 1:10000 dilution of alkaline phosphatase conjugated antibovine IgG (Sigma Chemical Co.) was added to each well and the plates were incubated at $37^{\circ} \mathrm{C}$ under the same conditions for $90 \mathrm{~min}$. Plates were washed five times with PBS-Tween. The appropriate substrate (p-nitrophenyl phosphate) was added and the plates were sealed and incubated for $40 \mathrm{~min}$ at room temperature. The plates were then read at $405 \mathrm{~nm}$ wavelength on a micro-ELISA reader (B.T.-100; Embrabio, São Paulo, Brazil). The cutoff values were calculated based on 10 noninfected water buffaloes sera [11].
TABLE 1: Summary of the serological detection of T. gondii, $N$. caninum, A. marginale, B. bovis, and B. bigemina using ELISA and IFAT. The results of ELISA were cross-tabulated with those of IFAT.

\begin{tabular}{lcccc}
\hline \multirow{2}{*}{ Agent } & \multirow{2}{*}{ ELISA $^{\mathrm{a}}$} & \multicolumn{2}{c}{ IFAT $^{\mathrm{b}}$} & \multirow{2}{*}{ ELISA/IFAT $^{\mathrm{c}}$} \\
\hline $\begin{array}{c}\text { Toxoplasma gondii } \\
(+)\end{array}$ & 1934 & 1672 & 262 & 1936 \\
$(-)$ & 2862 & 2 & 2860 & 2860 \\
& $\mathbf{4 7 9 6}$ & $\mathbf{1 6 7 4}$ & $\mathbf{3 1 2 2}$ & $\mathbf{4 7 9 6}$ \\
Neospora caninum & & & & \\
$(+)$ & 2599 & 2285 & 314 & 2601 \\
$(-)$ & 2197 & 2 & 2195 & 2195 \\
& $\mathbf{4 7 9 6}$ & $\mathbf{2 2 8 7}$ & $\mathbf{2 5 0 9}$ & $\mathbf{4 7 9 6}$ \\
Anaplasma marginale & & & & \\
$(+)$ & 2997 & 2393 & 604 & 3002 \\
$(-)$ & 1799 & 5 & 1794 & 1794 \\
& $\mathbf{4 7 9 6}$ & $\mathbf{2 3 9 8}$ & $\mathbf{2 3 9 8}$ & $\mathbf{4 7 9 6}$ \\
Babesia bigemina & & & & \\
$(+)$ & 1092 & 891 & 201 & 1100 \\
$(-)$ & 3704 & 8 & 3696 & 3696 \\
& $\mathbf{4 7 9 6}$ & $\mathbf{8 9 9}$ & $\mathbf{3 8 9 7}$ & $\mathbf{4 7 9 6}$ \\
Babesia bovis & & & & \\
$(+)$ & 1193 & 1075 & 118 & 1197 \\
$(-)$ & 3603 & 4 & 3599 & 3599 \\
& $\mathbf{4 7 9 6}$ & $\mathbf{1 0 7 9}$ & $\mathbf{3 7 1 7}$ & $\mathbf{4 7 9 6}$ \\
\hline
\end{tabular}

${ }^{a}$ Number of positive and negative buffaloes in ELISA assays.

${ }^{b}$ Number of positive and negative buffaloes in both ELISA and IFAT assays.

${ }^{c}$ The frequencies of positive and negative samples of combined ELISA and IFAT results.

2.3. IFAT for T. gondii, N. caninum, A. marginale, B. bovis, and $B$. bigemina. Briefly, a $10 \mu \mathrm{L}$ field serum sample diluted in PBS $(1: 40)$ was applied as the first antibody on the fixed smears and then incubated for $1 \mathrm{~h}$ at $37^{\circ} \mathrm{C}$ in a moist chamber. After washing with PBS three times, the fluorescein isothiocyanate (FITC)-conjugated sheep antibovine IgG antibody (Sigma, St. Louis, MO, USA) was applied as a secondary antibody $(1: 300)$ and then incubated for $1 \mathrm{~h}$ at $37^{\circ} \mathrm{C}$. The slides were washed three times with PBS and then examined using a fluorescent microscope (E400 Eclipse, Nikon, Kawasaki, Japan). Positive and negative control sera were added to each slide.

2.4. Statistical Analysis. The kappa coefficient was calculated to evaluate the agreement among the ELISA and IFAT. The chi-square test was used to evaluate significant differences $(P<0.05)$ of infection rate (T. gondii, N. caninum, A. marginale, $B$. bovis, and $B$. bigemina) in animals of different breed, reproductive status, and locations. The operational procedures were done using the $\mathrm{R}$ statistical software ( $\mathrm{R}$ Foundation for Statistical Computing, version 2.12.2, 2011).

\section{Results and Discussion}

IgG antibodies of $T$. gondii were detected in $41.33 \%$ (1982/4796) and $35.77 \%$ (1715/4796) of sampled buffaloes, by ELISA and IFAT, respectively (Table 1). 
Few reports have been done about the occurrence of $T$. gondii among buffaloes in Brazil [7]. Previous studies have reported a lower seroprevalence of this agent when compared to that observed among cattle. For instance, seroprevalence rates of $3.85 \%, 3.2 \%$, and $1.1 \%$ were found among buffaloes in states of Bahia [3], São Paulo [12], and Pará [12], respectively. A lower seroprevalence of $T$. gondii among buffaloes has also been reported in Turkey [13], Egypt [14], Vietnam [15], and Iran [16].

Antibodies of N. caninum were detected in $55.55 \%$ (2665/4796) and 48.88\% (2345/4796) of sampled buffaloes, by ELISA and IFAT, respectively (Table 1). Antibodies titers detected in seropositive animals ranged from 100 (cutoff) to 800: 100 (50\%), 200 (25\%), 400 (13.6\%), and 800 (11.4\%). Previous studies in the state of Pará have reported a seroprevalence of $N$. caninum ranging from $40.9 \%$ [17] to $70.15 \%$ [18] among buffaloes. On the other hand, a seroprevalence of $36.5 \%$ of N. caninum has been found among buffaloes from the state of Bahia [3]. The seroprevalence found here was higher than that found among buffaloes from Italy (34.6\%) [19] but lower than that found in Egypt (68\%) [14] and Argentina (64\%) [20]. However, it is noteworthy to mention that differences in reported seroprevalence could be explained also by the test utilized.

Herein, 64.7\% (3073/4796) and 50.0\% (2399/4796) of sampled buffaloes showed IgG antibodies to A. marginale, by ELISA and IFAT, respectively (Table 1). Although previous studies reported the occurrence of Babesia sp. among buffaloes $[9,11]$, those regarding the prevalence of $A$. marginale are scarce. In Brazil, seroprevalence of $A$. marginale among buffaloes (ranging from 31.1 to $80 \%$ ) is much different from that found among cattle (reaching in most cases 100\%) [21, 22]. In the present study, sampled buffaloes did not show clinical signs of anaplasmosis. Although clinical anaplasmosis is not usually seen among A. marginale infected buffaloes, manifestation of diseases such as hemolytic anemia, inapetence, depression, emaciation, melena, tachycardia, tachypnea, constipation, jaundice, and pale mucous was reported in buffaloes from India showing a low parasitaemia [23].

IgG antibodies to B. bovis and B. bigemina were detected in $24.9 \%(1193 / 4796)$ and $22.76 \%(1092 / 4796)$ by ELISA and $22.5 \%(1079 / 4796)$ and $18.74 \%(899 / 4796)$ by IFAT of sampled buffaloes, respectively (Table 1$)$. Thirteen percent $(623 / 4796)$ of animals were seropositive to both B. bovis and B. bigemina.

The low seroprevalence of $B$. bovis and B. bigemina found in the present study suggests a low transmission rate in the studied area due to the habitat where buffaloes are maintained, characterized by woods isolated from cattle infested by Babesia sp. infected ticks. A Low exposure of buffaloes to babesiosis agents could be explained by the fact that those animals live submerged in muddy waters, diminishing the probability of attachment of ticks and consequently the transmission of studied pathogens $[8,11]$. These findings classify the studied area as endemically instable for babesiosis agents in buffaloes, suggesting an elevated risk to babesiosis outbreaks in bovines, mainly in regions where cattle is raised closed to buffaloes or even when new animals are introduced in such herds.
The present study provides important information about the prevalence of T. gondii, N. caninum, A. marginale, B. bovis, and $B$. bigemina infections in water buffaloes. The real role of water buffaloes on the epidemiology of these diseases and, consequently, the impact of management and control programs targeting these animals should be determined.

\section{Conflict of Interests}

None of the authors of this work have a financial or personal relationship with other people or organizations that could inappropriately influence or bias the content of this paper.

\section{Acknowledgments}

The authors thank the Coordination for the Improvement of Higher Level of Education Personnel (CAPES) foundation and the National Counsel of Technological and Scientific Development $(\mathrm{CNPq})$ for financial support.

\section{References}

[1] Instituto Brasileiro de Geografia e Estatística (IBGE), www.ibge .gov.br.

[2] W. R. Cockrill, "The water buffalo: a review," British Veterinary Journal, vol. 137, pp. 8-16, 1981.

[3] L. F. P. Gondim, R. M. Souza, J. Guimarães, and M. A. O. Almeida, "Frequência de anticorpos contra Neospora caninum em búfalos criados no Estado da Bahia," in Proceedings of the Seminário Brasileiro de Parasitologia Veterinária, vol. 11, p. 227, Colégio Brasileiro de Parasitologia Veterinária, 1999.

[4] J. P. Dubey, A. L. Hattel, D. S. Lindsay, and M. J. Topper, "Neonatal Neospora caninum infection in dogs: isolation of the causative agent and experimental transmission," Journal of the American Veterinary Medical Association, vol. 193, no. 10, pp. 1259-1263, 1988.

[5] J. P. Dubey, G. Schares, and L. M. Ortega-Mora, "Epidemiology and control of neosporosis and Neospora caninum," Clinical Microbiology Reviews, vol. 20, no. 2, pp. 323-367, 2007.

[6] K. M. Kocan, J. de la Fuente, E. F. Blouin, J. F. Coetzee, and S. A. Ewing, "The natural history of Anaplasma marginale," Veterinary Parasitology, vol. 167, no. 2-4, pp. 95-107, 2010.

[7] J. B. Silva, A. H. Fonseca, S. J. T. Andrade, A. G. M. Silva, C. M. C. Oliveira, and J. D. Barbosa, "Prevalência de anticorpos antiToxoplasma gondii em búfalos (Bubalus bubalis) no Estado do Pará," Pesquisa Veterinária Brasileira, vol. 33, pp. 581-585, 2013.

[8] J. B. Silva, M. R. André, A. H. Fonseca et al., "Molecular and serological prevalence of Babesia bovis and Babesia bigemina in water buffaloes in the north region of Brazil," Veterinary Parasitology, vol. 197, pp. 678-681, 2013.

[9] J. B. Silva, M. R. André, A. H. Fonseca et al., "Molecular and serological prevalence of Anaplasma marginale in water buffaloes in the north region of Brazil," Ticks and Tick-Borne Diseases, 2013.

[10] Centro Panamericano de Zoonoses, "Prueba de doble difusión arco 5 para el diagnóstico de la hidatidosis humana," Nota Técnica, Centro Panamericano de Zoonoses, Buenos Aires, Argentina, 1979.

[11] M. A. Terkawi, N. X. Huyen, C. Shinuo et al., "Molecular and serological prevalence of Babesia bovis and Babesia bigemina in 
water buffaloes in the northeast region of Thailand," Veterinary Parasitology, vol. 178, no. 3-4, pp. 201-207, 2011.

[12] T. U. Fujii, N. Kasai, S. M. Nishi, J. P. Dubey, and S. M. Gennari, "Seroprevalence of Neospora caninum in female water buffaloes (Bubalus bubalis) from the southeastern region of Brazil," Veterinary Parasitology, vol. 99, no. 4, pp. 331-334, 2001.

[13] J. P. Dubey and C. P. Beattie, Toxoplasmosis of Animals and Man, CRC Press, Boca Raton, Fla, USA, 1988.

[14] J. P. Dubey, S. Romand, M. Hilali, O. C. H. Kwok, and P. Thulliez, "Seroprevalence of antibodies to Neospora caninum and Toxoplasma gondii in water buffaloes (Bubalus bubalis) from Egypt," International Journal for Parasitology, vol. 28, no. 3, pp. 527-529, 1998.

[15] L. T. T. Huong, B.-L. Ljungström, A. Uggla, and C. Björkman, "Prevalence of antibodies to Neospora caninum and Toxoplasma gondii in cattle and water buffaloes in southern Vietnam," Veterinary Parasitology, vol. 75, no. 1, pp. 53-57, 1998.

[16] S. Navidpour and N. Hoghooghi-Rad, "Seroprevalence of anti-Toxoplasma gondii antibodies in buffaloes in Khoozestan province, Iran," Veterinary Parasitology, vol. 77, no. 2-3, pp. 191194, 1998.

[17] S. P. Silva, R. A. Mota, E. B. Faria et al., "Occurrence of IgG antibodies anti-Neospora caninum and Toxoplasma gondii in female water buffaloes (Bubalus bubalis) raised in the Brazilian state of Pará," Pesquisa Veterinaria Brasileira, vol. 30, no. 5, pp. 443-446, 2010.

[18] S. M. Gennari, A. A. R. Rodrigues, R. B. Viana, and E. C. Cardoso, "Occurrence of anti-Neospora caninum antibodies in water buffaloes (Bubalus bubalis) from the Northern region of Brazil," Veterinary Parasitology, vol. 134, no. 1-2, pp. 169-171, 2005.

[19] A. Guarino, G. Fusco, G. Savini, G. Di Francesco, and G. Cringoli, "Neosporosis in water buffalo (Bubalus bubalis) in southern Italy," Veterinary Parasitology, vol. 91, no. 1-2, pp. 15-21, 2000.

[20] C. M. Campero, A. Pérez, D. P. Moore et al., "Occurrence of antibodies against Neospora caninum in water buffaloes (Bubalus bubalis) on four ranches in Corrientes province, Argentina," Veterinary Parasitology, vol. 150, no. 1-2, pp. 155-158, 2007.

[21] F. N. Corrêa, Estudo Epidemiológico de Borrelia burgdorferi, Babesia bovis, Babesia bigemina e Anaplasma marginale em Búfalos (Bubalus bubalis) do Estado do Rio de Janeiro [Tese de Doutorado], Universidade Federal Rural do Rio de Janeiro, Seropédica, Rio de Janeiro, Brazil, 2011.

[22] M. C. Vidotto, O. Vidotto, G. M. Andrade, G. Palmer, T. McElwain, and D. P. Knowles, "Seroprevalence of Anaplasma marginale in cattle in Parana State, Brazil, by MSP- 5 competitive ELISA," Annals of the New York Academy of Sciences, vol. 849, pp. 424-426, 1998.

[23] R. Srivastava and S. S. Ahluwalia, "A clinical case of anaplasmosis in buffalo," Indian Veterinary Journal, vol. 51, pp. 371-374, 1974. 

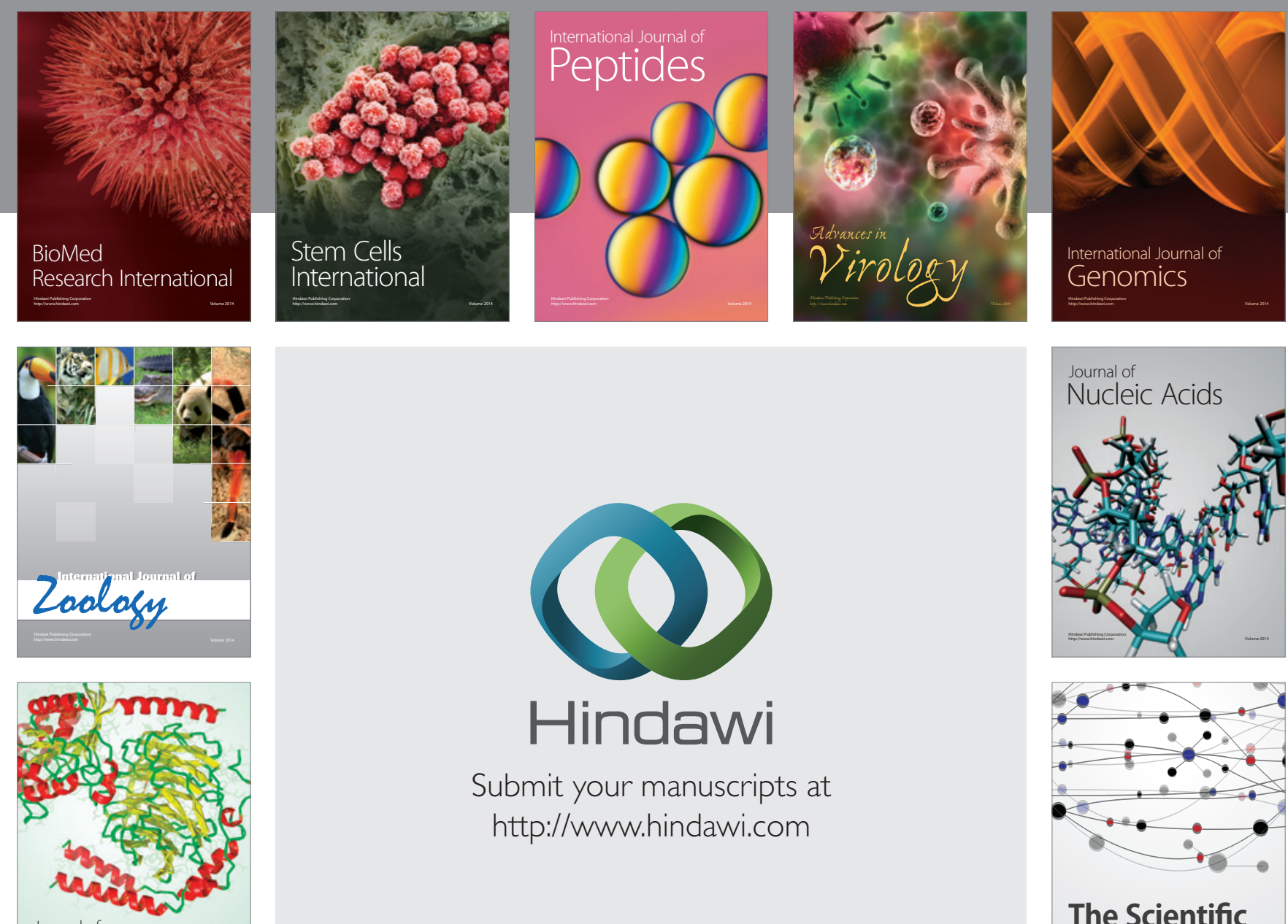

Submit your manuscripts at

http://www.hindawi.com

Journal of
Signal Transduction
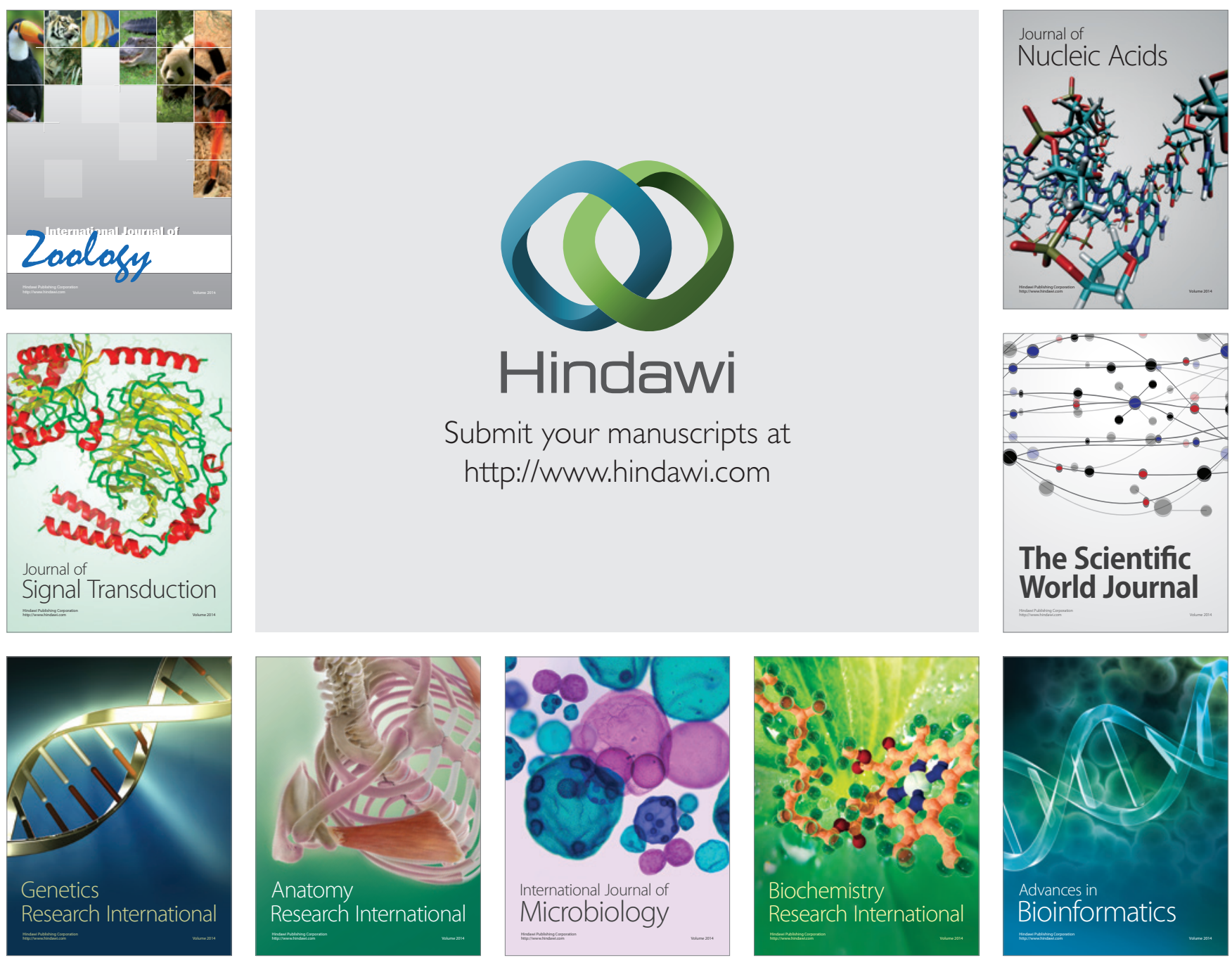

The Scientific World Journal
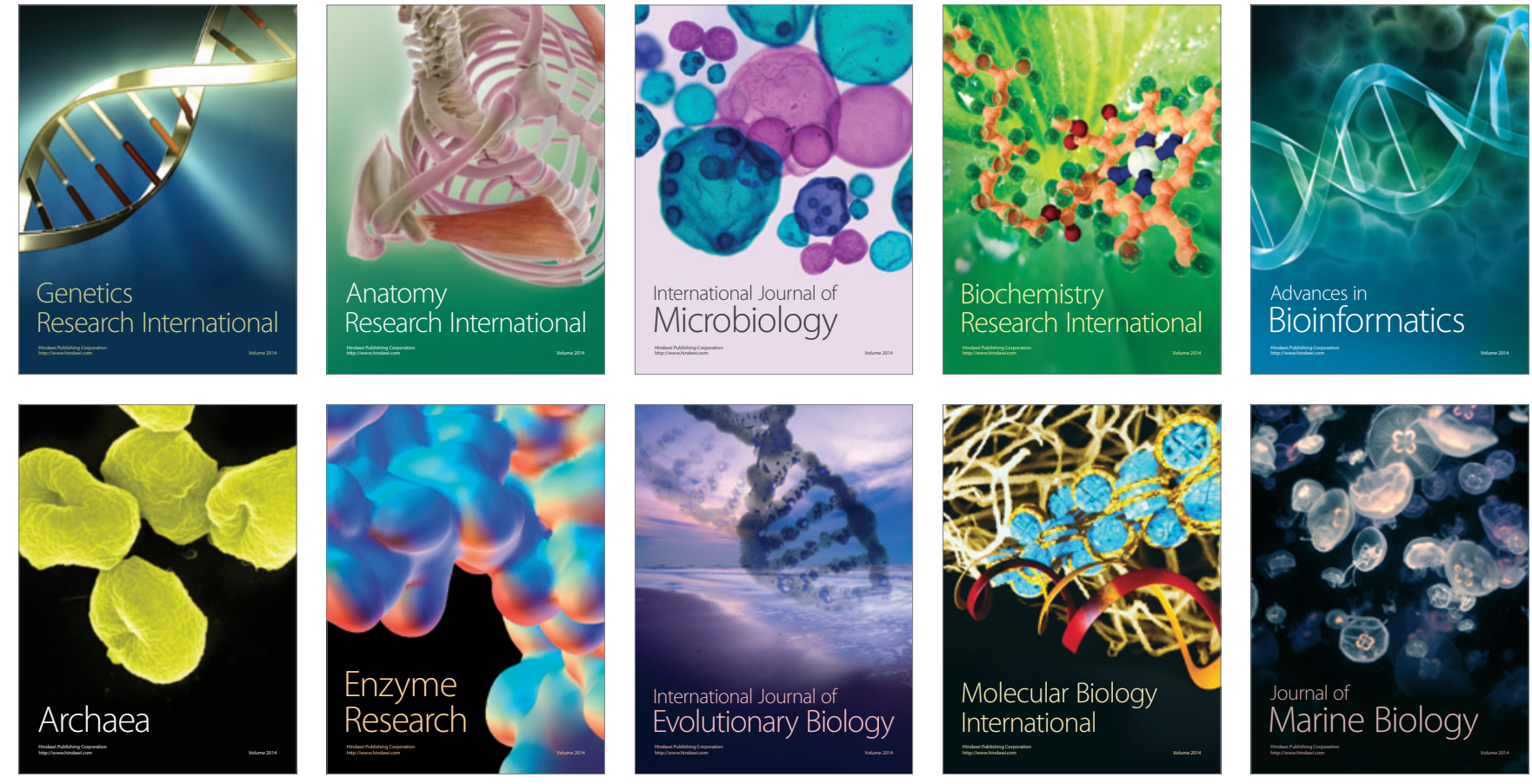